\title{
Cloning of a synthetic chimeric gene containing recombinant Mycoplasma hyopneumoniae antigens for expression in Pichia pastoris
}

\author{
Charles Gomes, Andressa Fisch, Silvana Marchioro, Lucas Tavares, Natasha Oliveira, Ana Peiter, Sérgio Jorge, \\ Odir Dellagostin
}

From 5th Congress of the Brazilian Biotechnology Society (SBBIOTEC)

Florianópolis, Brazil. 10-14 November 2013

\section{Background}

Mycoplasma hyopneumoniae is the primary etiologic agent of Swine Enzootic Pneumonia (EP), one of the most common respiratory disease that affects swine worldwide, causing considerable economic losses. Vaccination constitute one of the main practices to control EP. The production of recombinant experimental vaccines against EP has been considered an important approach towards the development of an improved vaccine [1]. This study aimed to clone a synthetic gene composed by the fusion of $M$. hyopneumoniae antigens R1 (P97), P42 and NrdF to Escherichia coli fragment $\mathrm{B}$ of the heat labile enterotoxin (LTB) into the vectors pPICZB (intracellular expression) and $\mathrm{pPICZ} \alpha \mathrm{B}$ (secreted expression), in order to produce this chimeric recombinant protein in Pichia pastoris and to test it as a vaccine candidate. The M. hyopneumoniae antigens were selected due to their capacity to confer partial protection in pigs when evaluated individually [2-4]. These antigens were associated to LTB, a potent mucosal and parenteral adjuvant.

\section{Methods}

The DNA fragment coding for the recombinant chimeric protein was designed in silico [5]. The synthetic gene and the vectors PPICZ $\alpha \mathrm{B}$ and PPICZB were digested with the enzymes BamHI and EcoRI and ligated. The ligation product was transformed into $E$. coli TOP10 strain, plated on Luria - Bertani (LB) culture medium containing the antibiotic Zeocin ${ }^{\mathrm{TM}}$ (Invitrogen). The resulting colonies were selected through a rapid screening method using a protocol with phenol - chloroform. Recombinant clones were

Laboratório de Biologia Molecular, Núcleo de Biotecnologia, Centro de Desenvolvimento Tecnológico, Universidade Federal de Pelotas, Pelotas, Brazil 
5. Tavares LA, Gomes CK, Fisch A, Marchioro S, Jorge S, Oliveira NR, Peiter AC, Conceição FR, Dellagostin OA: Design of synthetic gene for expression of a recombinant chimeric protein containing Mycoplasma

hyopneumoniae antigens. Proceedings of the $59^{\circ}$ Congresso Brasileiro de Genética: 16-19 September 2013; Águas de Lindóia .

doi:10.1186/1753-6561-8-S4-P247

Cite this article as: Gomes et al:: Cloning of a synthetic chimeric gene containing recombinant Mycoplasma hyopneumoniae antigens for expression in Pichia pastoris. BMC Proceedings 2014 8(Suppl 4):P247.

Submit your next manuscript to BioMed Central and take full advantage of:

- Convenient online submission

- Thorough peer review

- No space constraints or color figure charges

- Immediate publication on acceptance

- Inclusion in PubMed, CAS, Scopus and Google Scholar

- Research which is freely available for redistribution

Submit your manuscript at www.biomedcentral.com/submit
() Biomed Central 